\title{
Economic production of maize under chemical and granular organic fertilizer with hormone mixed formula, NPK and organic fertilizer
}

\author{
A.K. Keteku*, P. Intanon' ${ }^{1}$, S. Terapongtanakorn ${ }^{2}$ and R. Intanon ${ }^{3}$ \\ Faculty of Agriculture, \\ Natural Resources and Environment, Naresuan University, Phitsanulok 65000, Thailand. \\ Received: 13-02-2019 \\ Accepted: 20-05-2019
}

DOI: 10.18805/IJARe.A-422

\begin{abstract}
A new hybrid of maize (Pacific 999 Super) was investigated under six treatments; organic fertilizer (OF), chemical and granular organic fertilizer with hormone mixed formula A (HO-A), formula B (HO-B), formula C (HO-C), NPK-15-15-15 and control in 2017 and 2018 seasons at Phitsanulok, Thailand. The treatments were arranged in randomized complete block design (RCBD) with 3 replications. Fertilizer application rate was $300 \mathrm{~kg} / \mathrm{ha}$. Initial soil analysis had shown lower rates of NPK $(0.394 \%, 0.013 \%$ and $0.191 \%)$. The vegetative growth data showed that, mean plant height, leaf area, leaf chlorophyll and total dry matter/plant were highest in HO-C (255.49 cm, $158.37 \mathrm{dm}^{2}, 61.10$ and 299.62g, respectively). A maximum grain weight $(9,289.67 \mathrm{~kg} / \mathrm{ha})$, crude protein $(8.99 \%)$ and profit $(889.6$ \$ ha) were again recorded in HO-C. The results have demonstrated that the HO-C produced the greatest yield, income and is recommend for maize production.
\end{abstract}

Key words: Fertilizer, HO, Maize, Profit, Yield.

\section{INTRODUCTION}

Proper fertilization of maize is essential to secure a sustainable crop yield and soil productivity (Wei et al., 2016). Low soil fertility and inappropriate nutrient management are the major factors hindering crop productivity (Koireng et al., 2018). Most often smallholder farmers are unable to supply the necessary major and micro nutrients due to higher cost, resulting in imbalanced fertilization across the globe (Koireng et al., 2018). Hence, there is an urgent need to seek for an alternative cheaper nutrient source, which will reduce cost and maintain good soil health (Wei et al., 2016). Earlier studies by Khaliq et al. (2006) stated that, prudent combination of NPK, organic fertilizers and effective microorganisms (EM) improves soil properties. The low nutrient content of organic fertilizers hinders its use (Intanon et al., 2017). Li and Han (2016) pointed out the inability of inorganic fertilizers to promote long term soil sustainability.

A new chemical and granular organic fertilizer with hormone mixed formula (HO) was developed by Naresuan University, by combining inorganic fertilizer, soil amendments, mixed compost, bio-liquid hormone, herbal plant extracts and bio-liquid fertilizer (Intanon et al., 2017). Previous studies have reported that the various components of this fertilizer improves crop yield. The effect of hormones compound fertilizer and bio-fertilizer on rice growth and yield has been investigated (Jupkaew and Intanon, 2012).
Rice yield increased by $50 \%$ compare to the control. Similarly, Intanon et al., (2017) reported that the HO sugarcane formula increase sugarcane yield by $(320.6 \mathrm{~kg}$ / $\mathrm{ha}^{-1}$ ) than the control. However, the benefits of $\mathrm{OH}$ on maize yields in Phitsanulok still remain to be tested. Therefore in our study the HO maize formula was investigated on maize productivity.

\section{MATERIALS AND METHODS}

Experimental fertilizers: The NPK-15-15-15 and OF were procured from the Land Development Department of Thailand. OF was produce from chicken and pig manure. The material components of the HO fertilizers are shown in (Table 1).

Research location: The trial was conducted during 2017 and 2018 seasons at Phitsanulok, Thailand. Phitsanuluk is situated on $\left(16^{\circ} 55^{\prime} 0^{\prime \prime} \mathrm{N} / 100^{\circ} 30^{\prime} 0^{\prime \prime} \mathrm{E}\right.$, respectively). The soil of the site was sandy loam, under the Ultisols classification and poor in plant nutrients $(0.394 \% \mathrm{~N}, 0.013 \%$ $\mathrm{P}, 0.191 \% \mathrm{~K}, 4.40 \mathrm{mg} / \mathrm{kg} \mathrm{Ca}, 1.28 \mathrm{mg} / \mathrm{kg} \mathrm{Mg}, 0.22 \mathrm{mg} / \mathrm{kg} \mathrm{S}$, $0.536 \% \mathrm{OM}, 5.3 \mathrm{pH}$. The average monthly rainfall, maximum and minimum temperatures were during the trial were $73.12 \mathrm{~mm}, 34.1^{\circ} \mathrm{C}$ and $24.6^{\circ} \mathrm{C}$, respectively.

Research plan: The investigation was designed in RCBD with 3 replications. The treatment were; organic fertilizer (OF), chemical and granular organic fertilizer with hormone mixed formula A (HO-A), formula B (HO-B), formula C

*Corresponding author's e-mail: keteku.agbesi@yahoo.com

${ }^{1}$ Faculty of Agriculture, Natural Resources and Environment, Naresuan University, Phitsanulok 65000, Thailand.

${ }^{2}$ Department of Agricultural Science, Faculty of Agriculture, Ubon Ratchathani University, Ubon Ratchathani 34190, Thailand

${ }^{3}$ Faculty of Business, Economics and Communication, Naresuan University, Phitsanulok 65000, Thailand. 
Table 1: Material components of HO.

\begin{tabular}{lccc}
\hline Material components for maize & Kg & HO-B & HO-C \\
\hline Inorganic fertilizer (70\% NPK; 20\% Ca Mg S; 10\% Fe Zn Cu Mn) & HO-A & 25 & 30 \\
Soil amendments & 20 & 20 & 40 \\
Mixed compost & 25 & 25 & 15 \\
Bio-liquid hormone & 10 & 10 & 20 \\
Herbal plant extracts & 5 & 5 & 10 \\
Bio-liquid fertilizer & 15 & 11 & 5 \\
Total & $\mathbf{1 0 0}$ & $\mathbf{1 0 0}$ & 10 \\
\hline
\end{tabular}

(HO-C), NPK-15-15-15 and control (no fertilizer). The treatments were randomly allocated to plots of $6 \mathrm{~m} \times 5 \mathrm{~m}$. The hybrid corn (Pacific 999 Super) was planted at a seed rate and spacing of $18 \mathrm{~kg} / \mathrm{ha}$ and $75 \mathrm{~cm} \times 25 \mathrm{~cm}$, respectively. A fertilizer dose of $300 \mathrm{~kg} / \mathrm{h}$ a was used and $0.9 \mathrm{~kg}$ fertilizer was applied per plot. The fertilizer application was in two splits; $30 \%$ at 14 DAP and $70 \%$ at 45 DAP.

Fertilizer nutrient analysis: Total NPK contents were determined by the Kjeldahl method, Bray's no. II method and Neutral $\mathrm{N}$ ammonium method (Lu, 1999). Ca, Mg, Fe, $\mathrm{Mn}, \mathrm{Cu}$ and $\mathrm{Zn}$ were determined by wet digestion (Nitricperchloric digestion) method (Lu, 1999). Fertilizer $\mathrm{pH}$ was measured with electrode (H19017 Microprocessor) pH meter at a fertilizer water ratio of $1: 1.5$. The potassium dichromate oxidation method was adopted to determine organic matter (OM), while cation exchange capacity (CEC) was determined by the ammonium acetate method (Lu, 1999).

Vegetative data: Ten representative sample plants were randomly selected per plot for vegetative data collection. Observations on plant height, leaf area, leaf chlorophyll were collected after 14 DAP at 10 days interval till flowering 54 DAP. One representative plant was uprooted from each plot at after 14DAP at 20 days interval to investigate dry matter accumulation till harvesting. The plants were oven dried at $72 \pm 2^{\circ} \mathrm{C}$ for $24 \mathrm{hr}$ before weighing. The SPAD-502Plus meter was used to measure leaf chlorophyll content. Saxena and Singh (1965) formula was used to calculate leaf area plant $^{-1}$.

Leaf area/plant ${ }^{-1}\left(\mathrm{dm}^{2}\right)=(L \times D \times N \times 0.75)$

(Eqn 1)

Where; L, D and $\mathrm{N}$ are leaf length, leaf diameter and leaves number/plant respectively. 0.75 is leaf area constant for maize.

Yield and grain quality: Grain weight/plant was measured from the ten sample plants. The grains on each cobs/plot were individually weighed, summed up and recorded as grain weight/plot and converted to grain yield/ha. 100 seeds were randomly sampled from each plot, weighed and recorded as 100 seeds weight. The grains were measured at $13 \%$ moisture content using the moisture meter (FARMEX model, Delhi, India). Grain nitrogen content was analyzed by Kjeldahl digestion method (Yahya, 1996). The average N content of the two seasons was converted into crude protein content by the convection factor 5.68 (Sriperm et al., 2011).

Economics of production: Byerlee (1988) method was adopted for the economics studies. The average grain yield of the two seasons was use for the assessment. The cost incurred and the revenue obtain were considered. The prices were based on the standard market price given by the Ministry of Agriculture, Thailand. Benefit cost ratio (B: C) of each treatment was calculated as;

$$
\mathrm{B}: \mathrm{C}=\frac{\text { Total revenue }}{\text { Production cost }}
$$

Statistical analysis: The data recorded were subjected to Analysis of Variance (ANOVA) using the software package SPSS 17.0 for Windows (SPSS Inc., Chicago, USA). Difference between treatments means were separated by Duncan's multiple range test (DMRT) at a probability of $5 \%$.

\section{RESULTS AND DISCUSSION}

Analysis of the experimental fertilizers: The nutrient contents to the fertilizers varied statistically $(p<0.05)$ as shown in (Table 2). From the results OF, HO-A, HO-B and HO-C, contained (N P K Ca Mg S Fe Zn Cu and Mn). Nitrogen, phosphorus and potassium contents were highest in the NPK15-15-15 and HO-C treatments (10.920, 9.272 and $9.175 \%$, respectively). Similarly, the secondary and micro nutrients, $\mathrm{pH}$ and $\mathrm{CEC}$ were maximum in $\mathrm{HO}-\mathrm{C}$. OM was highest in OF (7.50\%). According to Wei et al. (2016) fertilization is one of the most important and manageable factor influencing crop growth. He stated that the type and value of fertilizer directly influence the release of nutrients. Therefore, balanced and optimum nutrients are of immense significance. The $\mathrm{pH}$ of all the fertilizers were at good level and would not hinder the release of nutrients.

Vegetative growth: Significant $(p<0.05)$ variations in maize growth were observed over the two seasons (Table 3). Maize height was significantly higher in all the treated plots compared to the control. The average highest height $(255.49 \mathrm{~cm})$ and leaf area/plant $\left(158.37 \mathrm{dm}^{2}\right)$ were noticed in HO-C. In the 2018 season, leaf area was not significant between HO-C (156.99 $\left.\mathrm{dm}^{2}\right)$ and NPK-15-15-15 $\left(148.09 \mathrm{dm}^{2}\right)$. Mean leaf chlorophyll contents were similar 
Table 2: Chemical analysis of the fertilizers.

\begin{tabular}{|c|c|c|c|c|c|c|c|c|}
\hline \multirow[b]{2}{*}{ Soil properties } & & & \multirow[b]{2}{*}{ OF } & \multicolumn{5}{|c|}{ Fertilizer treatments } \\
\hline & & & & NPK-15-15-15 & HO-A & HO-B & HO-C & $\mathrm{CD}(\mathrm{P} \leq \mathbf{0 . 0 5})$ \\
\hline \multirow[t]{3}{*}{ Primary nutrients } & $\mathrm{N}$ & $\%$ & 4.886 & 15.00 & 7.023 & 8.715 & 10.92 & $0.82 *$ \\
\hline & $\mathrm{P}$ & $\%$ & 4.650 & 15.00 & 6.518 & 7.802 & 9.272 & $0.82 *$ \\
\hline & $\mathrm{K}$ & $\%$ & 4.801 & 15.00 & 6.412 & 7.755 & 9.175 & $0.15 *$ \\
\hline \multirow[t]{3}{*}{ Secondary nutrients } & $\mathrm{Ca}$ & $\mathrm{mg} / \mathrm{kg}$ & 2.371 & 0.00 & 6.561 & 6.631 & 7.990 & $0.30^{*}$ \\
\hline & $\mathrm{Mg}$ & $\mathrm{mg} / \mathrm{kg}$ & 0.982 & 0.00 & 1.548 & 1.611 & 1.650 & $0.04 *$ \\
\hline & $\mathrm{S}$ & $\mathrm{mg} / \mathrm{kg}$ & 0.024 & 0.00 & 0.051 & 0.051 & 0.055 & $0.01 *$ \\
\hline \multirow[t]{4}{*}{ Supplementary nutrients } & $\mathrm{Zn}$ & $\mathrm{mg} / \mathrm{kg}$ & 0.498 & 0.00 & 1.504 & 1.593 & 1.658 & $3.86^{*}$ \\
\hline & $\mathrm{Cu}$ & $\mathrm{mg} / \mathrm{kg}$ & 0.024 & 0.00 & 0.047 & 0.048 & 0.056 & NS \\
\hline & $\mathrm{Fe}$ & $\mathrm{mg} / \mathrm{kg}$ & 2.42 & 0.00 & 9.61 & 11.23 & 14.11 & NS \\
\hline & $\mathrm{Mn}$ & $\mathrm{mg} / \mathrm{kg}$ & 0.75 & 0.00 & 1.32 & 1.51 & 1.74 & $0.04 *$ \\
\hline$(\mathrm{pH})=1: 1.5$ & & & 6.9 & 6.4 & 7.10 & 7.40 & 7.50 & $0.18^{*}$ \\
\hline Organic matter $\%$ & & & 1.39 & 0.00 & 1.08 & 1.16 & 1.27 & $0.07 *$ \\
\hline $\mathrm{CEC}(\mathrm{cmol} / \mathrm{kg})$ & & & 12.82 & 12.54 & 20.66 & 23.88 & 24.01 & $0.76^{*}$ \\
\hline
\end{tabular}

* Significant at $\mathrm{P} \leq 0.05$; NS- Non Significant at $\mathrm{P}>0.05$.

Table 3: Vegetative growth.

\begin{tabular}{|c|c|c|c|c|c|c|c|c|c|c|c|c|}
\hline \multirow[t]{2}{*}{ Treatments } & \multicolumn{3}{|c|}{ Plant height (cm) } & \multicolumn{3}{|c|}{ Leaf area/plant $\left(\mathbf{d m}^{2}\right)$} & \multicolumn{3}{|c|}{$\begin{array}{l}\text { Leaf chlorophyll } \\
\text { (SPAD unit) }\end{array}$} & \multicolumn{3}{|c|}{ Total dry matter (g) } \\
\hline & 2017 & 2018 & mean & 2017 & 2018 & mean & 2017 & 2018 & mean & 2017 & 2018 & mean \\
\hline OF & 205.45 & 215.89 & 210.67 & 94.65 & 95.21 & 94.93 & 47.76 & 49.49 & 48.62 & 174.81 & 176.77 & 175.79 \\
\hline $\mathrm{HO}-\mathrm{A}$ & 220.36 & 235.12 & 227.74 & 126.05 & 126.61 & 126.33 & 56.89 & 58.62 & 57.75 & 227.32 & 229.29 & 228.30 \\
\hline HO-B & 222.85 & 239.26 & 231.05 & 134.97 & 135.54 & 135.25 & 60.45 & 62.18 & 61.31 & 271.56 & 273.52 & 272.54 \\
\hline $\mathrm{HO}-\mathrm{C}$ & 250.94 & 260.04 & 255.49 & 159.76 & 156.99 & 158.37 & 61.24 & 60.97 & 61.10 & 298.64 & 300.61 & 299.62 \\
\hline NPK 15-15-15 & 226.22 & 259.99 & 243.10 & 147.81 & 148.38 & 148.09 & 60.22 & 61.95 & 61.08 & 263.30 & 265.27 & 264.28 \\
\hline Control & 156.69 & 153.46 & 155.08 & 76.20 & $66.43^{\mathrm{d}}$ & 71.31 & 20.03 & 19.43 & 19.73 & 149.19 & 127.82 & 138.51 \\
\hline $\mathrm{CD}(\mathrm{P} \leq 0.05)$ & 47.89 & 48.59 & $21.97 *$ & 10.52 & 16.18 & $7.57 *$ & 4.46 & 4.14 & $2.04 *$ & 21.4 & 30.76 & $17.31 *$ \\
\hline
\end{tabular}

*Significant at $\mathrm{P} \leq 0.05$.

in HO-B, HO-C, NPK-15-15-15 and HO-A (61.31, 61.10, 61.08 and 57.75, respectively) due to their high $\mathrm{N}$ content. In addition, total dry matter weights were highest (298.64 and 300.61g) in HO-C in both seasons. A slight increase in growth was noticed in 2018. Similarly, the OF treatment also showed superior growth compared to the control. According to Sreedevi et al. (2018) the effect of fertilizers on nutrient availability to crop can be observed from their impact on vegetative growth. In our work, vegetative growth was in accordance with the nutrient status of the treatments. Besides having $\mathrm{N}$, an important element in cell division in the fertilizers, secondary and minor nutrients also relates to cell division, the construction of chlorophyll and photosynthesis (Sreedevi et al., 2018; Intanon et al. 2017). The greater dry matter produced by HO-C, HO-B and NPK-15-15-15 may be due to the availability of more green area for photosynthesis, due to their high plant height and leaf area/ plant. Again, the presence of OM in OF and $\mathrm{HO}$ group may had increased nutrients availability. It is noteworthy to mention that, vegetative growth was greater under the NPK treatment compared to OF and as well, produced greater dry matter weight (264.28 g) over HO-A (228.30 g) owing to its higher levels of NPK. Our results concur with that of
Zerihun et al. (2013) who reported a maize height of $232.9 \mathrm{~cm}$ under 110/46 NP + $16 \mathrm{t} /$ ha farmyard manure (FYM) and $236.2 \mathrm{~cm}$ under $110 / 46 \mathrm{NP}+4 \mathrm{t} / \mathrm{ha}$.

Yield and grain quality: Grain weight and 100 seeds weight increased slightly in 2018 under all fertilizers. In contrast, a decrease was noticed in the control plot (Table 4). The mean highest grains and 100 seeds weight/plant (166.23g and $37.90 \mathrm{~g}$, respectively) were observed in HO-C. This lead to a greater average grain yield $/$ ha of $(9289.67 \mathrm{~kg})$, followed by HO-B and NPK treatments in (Table 5). The performance of the HO-C might be due to the higher vegetative growth resulting from optimum balanced nutrients supply (Wei et al., 2016); which might have resulted in higher nutrients uptake and better translocation of assimilates from source to sink for greater yield. In our results, the treatments with higher $\mathrm{P}$ content and a balance of other nutrients (Table 2) produced the greatest yield. Although the NPK treatment had no secondary and minor nutrients, because of its high $\mathrm{P}$ content (15\%), grain yield was higher. Also, ( $\mathrm{N} \mathrm{S} \mathrm{Mg} \mathrm{Fe} \mathrm{Cu}$ and $\mathrm{Zn}$ ) are major factors in the synthesis of carbohydrate and sugar, hence under their adequate supply more organic compound were produced in $\mathrm{HO}-\mathrm{C}$ and $\mathrm{HO}-\mathrm{B}$. As a result, there were weight gains in terms of grain weight plant ${ }^{-1}$. The 
average grain nitrogen contents (1.58 and $1.53 \%)$ and crude protein (8.99 and $8.67 \%$ ) were highest in HO-C and NPK15-15-15 (Table 5). The HO and NPK influenced higher grain weight than OF. Grain weight/plot between HO-A $(24.29 \mathrm{~kg})$ and $\mathrm{OF}(22.12 \mathrm{~kg})$ were not significant. Our findings are in agreement with Kumar et al. (2010) report

Table 4: Maize yield and yield components.

\begin{tabular}{|c|c|c|c|c|c|c|c|c|c|}
\hline \multirow[t]{2}{*}{ Treatments } & \multicolumn{3}{|c|}{ Grain weight/plant (g) } & \multicolumn{3}{|c|}{100 seeds weight $(\mathrm{g})$} & \multicolumn{3}{|c|}{ Grain weight/plot (kg) } \\
\hline & 2017 & 2018 & mean & 2017 & 2018 & mean & 2017 & 2017 & mean \\
\hline GF & 125.93 & 127.27 & $126.60^{b}$ & 31.20 & 34.40 & 32.80 & 21.46 & 22.79 & 22.12 \\
\hline $\mathrm{HO}-\mathrm{A}$ & 155.60 & 156.93 & $156.27^{\mathrm{a}}$ & 33.50 & 37.57 & 35.53 & 23.80 & 24.79 & 24.29 \\
\hline HO-B & 159.57 & 160.90 & 160.23 & 35.27 & 38.37 & 36.82 & 26.34 & 27.00 & 26.67 \\
\hline $\mathrm{HO}-\mathrm{C}$ & 165.57 & 166.90 & 166.23 & 36.00 & 39.80 & 37.90 & 27.21 & 28.53 & 27.87 \\
\hline NPK 15-15-15 & 156.41 & 157.74 & 157.08 & 34.77 & 38.23 & 36.50 & 25.88 & 26.20 & 26.04 \\
\hline Control & 98.50 & 92.17 & 95.33 & 29.87 & 27.17 & 28.52 & 16.74 & 11.40 & 14.07 \\
\hline $\mathrm{CD}(\mathrm{P} \leq 0.05)$ & 20.59 & 19.52 & $19.66^{*}$ & 2.70 & 5.02 & $3.36 *$ & 2.76 & 2.97 & $2.39 *$ \\
\hline
\end{tabular}

*Significant at $\mathrm{P} \leq 0.05$.

Table 5: Maize yield and grain quality.

\begin{tabular}{|c|c|c|c|c|c|c|c|}
\hline \multirow{2}{*}{$\begin{array}{l}\text { Treatments } \\
\left(50 \mathrm{~kg} / \mathrm{ha}^{-1}\right)\end{array}$} & \multicolumn{3}{|c|}{ Grain yield/ha kg } & \multicolumn{3}{|c|}{ Grain nitrogen \% } & \multirow{2}{*}{$\begin{array}{l}\text { Crude protein } \\
\text { content } \%\end{array}$} \\
\hline & 2017 & 2018 & mean & 2017 & 2018 & mean & \\
\hline $\mathrm{OF}$ & 7153.00 & 7595.22 & 7374.11 & 1.02 & 1.23 & 1.12 & 6.38 \\
\hline $\mathrm{HO}-\mathrm{A}$ & 7931.67 & 8262.78 & 8097.22 & 1.03 & 1.22 & 1.13 & 6.40 \\
\hline HO-B & 8778.56 & 8998.56 & 8888.56 & 1.24 & 1.58 & 1.41 & 8.03 \\
\hline $\mathrm{HO}-\mathrm{C}$ & 9068.56 & 9510.78 & 9289.67 & 1.54 & 1.63 & 1.58 & 8.99 \\
\hline NPK 15-15-15 & 8625.56 & 8734.44 & 8680.00 & 1.44 & 1.61 & 1.53 & 8.67 \\
\hline Control & 5580.22 & 3800.22 & 4690.22 & 0.92 & 0.90 & 0.91 & 5.17 \\
\hline $\mathrm{CD}(\mathrm{P} \leq 0.05)$ & 921.20 & 989.47 & $1567.88 *$ & 0.24 & 0.23 & $0.22 *$ & $1.23 *$ \\
\hline
\end{tabular}

*Significant at $\mathrm{P} \leq 0.05$.

Table 6: Research expenditure.

\begin{tabular}{|c|c|c|c|c|c|}
\hline \multirow[t]{2}{*}{ Expenditure } & \multicolumn{4}{|c|}{ Cost } & \multirow[b]{2}{*}{$\$ /$ ton } \\
\hline & Price/unit \$ & Quantity & $\$ /$ ha & & \\
\hline \multicolumn{6}{|l|}{ Materials costs } \\
\hline \multicolumn{6}{|l|}{ Basic material costs:- } \\
\hline Seed cost & 47.6 & 3.6 bags & 171.4 & & \\
\hline Allacore weed control pill & 4.8 & 6 box & $\underline{28.6}$ & 200.0 & \\
\hline \multicolumn{6}{|l|}{ Fertilizer cost:- } \\
\hline Control & - & & & - & \\
\hline NPK:15-15-15 & 27.9 & 6bags & & 167.6 & \\
\hline $\mathrm{HO}-\mathrm{A}$ & 21.6 & 6bags & & 129.5 & \\
\hline HO-B & 24.8 & 6bags & & 148.6 & \\
\hline $\mathrm{HO}-\mathrm{C}$ & 27.9 & 6bags & & 167.6 & \\
\hline OF & 14.3 & 6bags & & 85.7 & \\
\hline \multicolumn{6}{|l|}{ Labour cost } \\
\hline \multicolumn{6}{|l|}{ Basic labour costs:- } \\
\hline Labor cost for ploughing & 79.4 & & 158.7 & & \\
\hline Labour cost for spraying herbicide & & & 50.8 & & \\
\hline Labour cost for planting & & & 131.7 & 341.2 & \\
\hline Labour cost for fertilizer application & & & & 63.5 & \\
\hline Labour cost for harvesting & & & & & 20.6 \\
\hline Labour cost for transporting yield & & & & & 15.9 \\
\hline \multicolumn{6}{|l|}{ Other costs } \\
\hline Basic cost for pumps and spraying & & & & 9.5 & \\
\hline Fertilizer transportation cost & & & & 9.5 & \\
\hline Maize threshing cost & & & & & 11.1 \\
\hline Cost of storage sacks (1.3\$ /sack) & & & & & 25.4 \\
\hline
\end{tabular}


Table 7: Production cost and profit.

\begin{tabular}{|c|c|c|c|c|c|c|c|}
\hline Details & $\overline{\text { OF }}$ & HO-A & HO-B & HO-C & NPK (15-15-15) & Control & $\overline{\mathrm{CD}(\mathrm{P} \leq 0.05)}$ \\
\hline \multicolumn{8}{|l|}{ Material Cost } \\
\hline Basic material cost $\$ /$ ha & 200.0 & 200.0 & 200.0 & 200.0 & 200.0 & 200.0 & \\
\hline Fertilizer cost $\$ /$ ha & 85.7 & 129.5 & 148.6 & 167.6 & 167.6 & 0.0 & \\
\hline \multicolumn{8}{|l|}{ Labour Cost } \\
\hline Basic labour cost $\$ /$ ha & 341.3 & 341.3 & 341.3 & 341.3 & 341.3 & 341.3 & \\
\hline Fertilizer application cost $\$ / \mathrm{ha}$ & 63.5 & 63.5 & 63.5 & 63.5 & 63.5 & 0.0 & \\
\hline Harvesting cost \$/ton & 152.2 & 167.1 & 183.4 & 191.7 & 179.1 & 96.8 & \\
\hline Yield transportation cost $\$ /$ ton & 117.1 & 128.5 & 141.1 & 147.5 & 137.8 & 74.4 & \\
\hline \multicolumn{8}{|l|}{ Other cost } \\
\hline Total basic other costs $\$ /$ ha & 9.5 & 9.5 & 9.5 & 9.5 & 9.5 & 9.5 & \\
\hline Fertilizer transportation cost $\$ /$ ha & 9.5 & 9.5 & 9.5 & 9.5 & 9.5 & 0.0 & \\
\hline Maize threshing cost $\$ /$ ton & 81.9 & 90.0 & 98.8 & 103.2 & 96.4 & 52.1 & \\
\hline Maize storage sacks \$/ton & 187.3 & 205.6 & 225.7 & 235.9 & 220.4 & 119.1 & \\
\hline Total production cost $\$ / \mathrm{ha}$ & 1248.0 & 1344.6 & 1421.4 & 1469.7 & 1425.2 & 893.2 & \\
\hline \multicolumn{8}{|l|}{ Revenue } \\
\hline Sale of Grain $0.254 \$ / \mathrm{kg}$ & 1872.8 & 2056.4 & 2257.4 & 2359.3 & 2204.4 & 1191.2 & \\
\hline Profit $\$ /$ ha & 624.8 & 711.9 & 836.0 & 889.6 & 779.2 & 298.0 & $126.5^{*}$ \\
\hline Benefit: Cost ratio (B:C) & 1.50 & 1.53 & 1.59 & 1.61 & 1.55 & 1.33 & NS \\
\hline
\end{tabular}

*Significant at $\mathrm{P} \leq 0.05$; NS- Non Significant at $\mathrm{P}>0.05$.

that $75 \% \mathrm{~N} / \mathrm{ha}+60 \mathrm{~kg} \mathrm{P_{2 }} \mathrm{O}_{5} / \mathrm{ha}+60 \mathrm{~kg} \mathrm{~K} \mathrm{O} / \mathrm{ha}+5 \mathrm{~L}$ Azotobacter/ha $+1 \%$ enriched banana sap, produced the highest yield. Khaliq et al. (2006) recorded the highest seed cotton yield $(2470 \mathrm{~kg} / \mathrm{ha})$ under $\mathrm{N}_{170} \mathrm{P}_{85} \mathrm{~K}_{60}+\mathrm{EM}+\mathrm{OM}$ fertilization. Consistently, Agegnehu et al. (2016) also recorded $(8.08 \mathrm{t} / \mathrm{ha})$ of maize seed yield in a trail of $\mathrm{N}_{150}$ $\mathrm{P}_{41} \mathrm{~K}_{120} \mathrm{~S}_{3} \mathrm{~kg} / \mathrm{ha}+10 \mathrm{t} / \mathrm{ha}$ biochar $+25 \mathrm{t} / \mathrm{ha}$ compost.

Economic impact: From the (Tables 6 and 7), cost of production and revenue were highest (1469.7 and 2359.3\$/ ha) in HO-C followed in cost by NPK (1425.2 \$/ha) and HO-B (1421.4 and 2257.4\$/ha) According to our findings, the maximum profit $(889.6 \$ / \mathrm{ha})$ was again realized under HO-C due to its higher yield. The profit of HO-B (836.0 \$/ ha) and NPK (779.2 \$/ha) were on a par. The percentage increase in profit of HO-C, HO-B and NPK were $66.5 \%$, $64.4 \%$ and $61.8 \%$, respectively) compared to the control. The $\mathrm{B}: \mathrm{C}$ ratio of the treatments were not significant, however the best (1.61) was in HO-C, followed by HO-B (1.59), NPK (1.55), HO-A (1.53), OF (1.50) and control (1.53).

\section{CONCLUSION}

Our findings have shown that, HO-C, HO-B and NPK-15-15-15 produced the highest maize growth, yield (9289.67, 8888.56 and $8680.00 \mathrm{~kg} / \mathrm{ha}$, respectively) and profit (889.6, 836.0 and $779.2 \$ / \mathrm{ha}$, respectively). It was evident from the results that, balance supply of major and micro nutrients promotes maximum maize yield and farmer income. In addition, the combination of inorganic and organic nutrient sources as in $\mathrm{HO}$ can build up the soil organic matter content and help increase nutrients availability to crop for greater yield. The control produced the lowest maize yield and profit. The B: $\mathrm{C}$ ratios of the fertilizers showed a positive economic implication. Agriculture policies should therefore encourage the inclusion of micro nutrients in fertilizer plans. We recommend the HO-C formula for maize production.

\section{ACKNOWLEDGEMENT}

The authors are thankful to the Naresuan University International Scholarship Scheme for sponsoring this research.

\section{REFERENCES}

Agegnehu, G., Bass, A.M., Nelson, P.N., Bird, M.I. (2016). Benefits of biochar, compost and biochar-compost for soil quality, maize yield and greenhouse gas emissions in a tropical agricultural soil. Science of the Total Environment. 543: 295-306.

Byerlee, D. (1988). An economics training manual. Agronomic data to farmer's recommendation, CIMMYT, Mexico.

Intanon, P., Keteku, A.K., Intanon, R. (2017). Effect of different materials on soil pH improvement, soil properties, growth, yield and quality of sugarcane. Proceeding of the East and Southeast Asia Federation of Soil Scientist. 13: 50-59.

Jupkaew, S. and Intanon, P. (2012). Effect of hormones compound granular fertilizer on growth and yield of rice. Khon Kaen Agriculture. Journal. 40: 105-109.

Khaliq, A., Abbasi, M.K., Hussain, T. (2006). Effects of integrated use of organic and inorganic nutrient sources with effective microorganisms on seed cotton yield in Pakistan. Bioresource Technology. 97: 967-972.

Koireng, R.J., Singh, L.N., Devi, Kh. P. (2018). Integration of different sources of organic manure and micro-nutrients on growth, yield and quality of potato (Solanum tuberosum L.) grown under new alluvial soil condition. Indian Journal of Agricultural Research. 52: 172-176. 
Kumar, R., Ram, M., Gaur, G.S. (2010). Effect of GA3 and Ethrel on growth and flowering of African marigold cv. Pusa Narangi Gainda. Indian Journal of Horticulture. 67: 362-366.

Li, L.J. and Han, X.Z. (2016). Changes of soil properties and carbon fractions after long-term application of organic amendments in Mollisols. CATENA. 143: 140-144.

Lu, R.K. (1999). Analytical methods of soil and agricultural chemistry. China Agricultural Science and Technology Press. Beijing. pp. $107-240$

Saxena, M.C. and Singh, Y. (1965). A note on area estimation of intact maize leaves. Indian Journal of Agronomy. 10: $437-439$.

Sreedevi, B., Arun, M.N., Krishnamurthy, P., Sandyarani, A., Kumar, R.M., Viraktamath, B.C. (2018). Impact of nutrient management on performance of rice (Oryza sativa)- blackgram (Vigna mungo L.) cropping system. Indian Journal of Agricultural Research. 52: 637-642.

Sriperm, N., Pestia, G., Tillmanb, P.B. (2011). Evaluation of the fixed nitrogen-to-protein (N:P) conversion factor (6.25) versus ingredient specific N: P conversion factors in feedstuffs. Journal of the Science of Food and Agriculture. 91: 1182-1186.

Wei, W., Yan, Y., Cao, J., Christie, P., Zhang, F., Fan, M. (2016). Effects of combined application of organic amendments and fertilizers on crop yield and soil organic matter: An integrated analysis of long-term experiments. Agriculture, Ecosystems and Environment. 225: 86-92.

Yahya, A. (1996). Effects of fertilizer rate on leaf nutrient composition, growth, flowering and quality of marigold plants. Journal of Tropical Agriculture and Food Science. 24: 13-18.

Zerihun, A., Sharma, J.J., Nigussie, D., Kanampiu, F. (2013). Effect of integrated organic and inorganic fertilizer rates on performances of soybean and maize component crops of a soybean/maize mixture. African Journal of Agricultural Research. 8: 3921-3929.

Zhang, F., Cui, Z., Chen, X., Ju, X., Shen, J., Chen, Q., Liu, X., Zhang, W., Mi, G., Fan, M., Jiang, R. (2012). Chapter one-Integrated nutrient management for food security and environmental quality in China. In D. L. Sparks (Ed.), Advances in Agronomy, Academic Press. pp. 1-40. 